\title{
Lost Conservation Opportunities in the Pacific Northwest Irrigation Sector
}

B. J. Harrer

M. P. Hattrup

June 1987

Prepared for the U.S. Department of Energy under Contract DE-AC06-76RLO 1830

Pacific Northwest Laboratory Operated for the U.S. Department of Energy by Battelle Memorial Institute 


\section{DISCLAIMER}

This report was prepared as an account of work sponsored by an agency of the United States Government. Neither the United States Government nor any agency thereof, nor Battelle Memorial Institute, nor any of their employees, makes any warranty, expressed or implied, or assumes any legal liability or responsibility for the accuracy, completeness, or usefulness of any information, apparatus, product, or process disclosed, or represents that its use would not infringe privately owned rights. Reference herein to any specific commercial product, process, or service by trade name, trademark, manufacturer, or otherwise, does not necessarily constitute or imply its endorsement, recommendation, or favoring by the United States Government of any agency thereof, or Battelle Memorial Institute. The views and opinions of authors expressed herein do not necessarly state or reflect those of the United States Government or any agency thereof, or Battelle Memorial Institute.

\section{PACIFIC NORTHWEST LABORATORY operated by \\ BATTELLE MEMORIAL INSTITUTE \\ for the \\ UNITED STATES DEPARTMENT OF ENERGY under Contract DE-AC06-76RLO 1830}

\begin{tabular}{|c|c|}
\hline \multirow{2}{*}{\multicolumn{2}{|c|}{ Printed in the United States of America }} \\
\hline & \\
\hline \multirow{2}{*}{\multicolumn{2}{|c|}{$\begin{array}{l}\text { National Technical Information Service } \\
\text { United States Department of Commerce }\end{array}$}} \\
\hline & \\
\hline \multicolumn{2}{|c|}{5285 Port Royal Road } \\
\hline \multicolumn{2}{|c|}{ Springfield, Virginia 22161} \\
\hline \multirow{2}{*}{\multicolumn{2}{|c|}{$\begin{array}{l}\text { NTIS Price Codes } \\
\text { Microfiche A01 }\end{array}$}} \\
\hline & \\
\hline \multicolumn{2}{|c|}{ Printed Copy } \\
\hline & Price \\
\hline Pages & Codes \\
\hline $001-025$ & A02 \\
\hline 026-050 & A03 \\
\hline 051-075 & A04 \\
\hline $076-100$ & A05 \\
\hline $101-125$ & A06 \\
\hline 126-150 & A07 \\
\hline $151-175$ & $\mathrm{~A} 0 \mathrm{~B}$ \\
\hline $176-200$ & A09 \\
\hline $201-225$ & A010 \\
\hline $226-250$ & A011 \\
\hline $251-275$ & A012 \\
\hline $276-300$ & A013 \\
\hline
\end{tabular}


B. J. Harrer

M. P. Hattrup

June 1987

Prepared for the U.S. Department of Energy under Contract DE-ACO6-76RLO 1830

Pacific Northwest Laboratory Richland, Washington 99352 
. 


\section{SUMMARY}

This paper presents an analysis of "lost opportunities" for energy conservation in the irrigation sector of the Pacific Northwest region. Lost opportunities are generally defined as conservation measures whose implementation at a later date would be substantially more expensive or less effective in saving energy than would current implementation. An example of a lost opportunity would be window design orientation on new buildings. Bonneville is currently in the process of identifying and evaluating potential lost opportunities in all electric energy-consuming sectors so that future electricity needs can be most efficiently met.

Initial efforts in the study were focused on identifying potential lost opportunities. The results of these efforts resulted in the following measures being identified as potential lost opportunities in the irrigation sector:

- pumping plant efficiency improvements on both existing and new sprinkler irrigated acres

- low-pressure irrigation on new sprinkler acres

- mainline modification and fittings redesign on new sprinkler acres

All of these potential lost opportunities except fittings design were subject to more detailed analyses through a survey of irrigation equipment dealers, pump repairers and county extension agents. Fittings design was omitted from the survey because it was felt to be too undefined to gather empirical field data on and because of its small energy savings potential.

The results of the survey indicated that only high-efficiency electric motors and correct pump selection methods on existing and new sprinkler systems and low-pressure irrigation on new handmove/sideroll systems should be considered lost opportunities. Irrigation pumps and motors are replaced at a minimum of every 10 to 15 years. Some modification of a pump to improve its energy efficiency is possible after it is first installed, but pump puling costs and technical barriers limit the potential for obtaining energy savings from a pump that is incorrectly matched to irrigation system requirements. Modification of the internal components of an electric motor after it is installed is even more difficult. Because of the difficulty of making 
major modifications to pumping plant components once they are installed and because of the long lives of these components, pump selection and highefficiency electric motors are identified as lost opportunities.

Irrigation systems, such as handmove/sideroll systems, will normally last at least 20 years without requiring major replacements. Currently, management requirements and concerns about inadequate water coverage appear to be limiting the adoption of low-pressure irrigation on handmove/sideroll systems. Systems specifically designed to use low pressure on new acres offer the potential to facilitate adoption of this measure.

Other conservation measures were eliminated from consideration as lost opportunities based on the following findings:

- Low-pressure on new center-pivot systems is almost universally being adopted and no additional costs are associated with adopting lowpressure rather than high-pressure on new acres.

- Pumping plant efficiency improvements other than correct pump selection methods and high-efficiency motors (such as improved plant maintenance) are not likely to last for 10 years.

- Installing a parallel mainline after a new irrigation system is developed will generally not cost more than $50 \%$ above installing a larger mainline at the time of system development.

Two other significant findings of the survey were the following:

- Lost opportunities on new acres currently do not appear to represent a significant problem because so few new acres are currently being developed; this situation is expected to continue for the next five years.

- Education and information continue to represent a significant barrier to the adoption of conservation measures in the irrigation sector.

The identified lost opportunity of correct pump selection involves the matching of pump flow rate and operating head characteristics with the requirements of an irrigation system. Information obtained in this study and others indicates that improper pump selection by irrigators is often a major contributor to pumping plant energy efficiency losses and that the primary 
contributor to improper pump selection is a lack of information and education on correct pump selection procedures. Because of its minimal acquisition cost, this lost opportunity was not subjected to detailed cost analysis, but it is a conservation resource that Bonneville should be aware of in its planning activities. Its estimated energy savings are likely to fall in the range of 5 to 10 average $\mathrm{MW}$.

The two other measures identified as lost opportunities were subjected to more detailed analysis. The primary factor limiting the adoption of low-pressure on new handmove/sideroll systems was found to be technical design considerations related to the prevalent use of $6^{\prime}$ wheels on sideroll systems and $40^{\prime} \times 60^{\prime}$ spacing. Approximately 7.5 average WW of electrical energy savings are associated with this lost opportunity on new handmove/sideroll systems and increasing the adoption of low-pressure on new systems would likely have the additional benefit of facilitating adoption on existing systems. These savings could likely be obtained for an average cost of less than 10 milis per kWh saved over a 20-year measure life.

Approximately 16.5 average NW of savings are associated with the lost opportunity of high-efficiency motors on existing and new sprinkier irrigated acres. These savings could generally be obtained at a cost of 25 mills per kWh saved or less. Based on a number of conversations with pump repairers and dealers, expected measure life for this lost opportunity is 15 years. All of the conservation measures identified as lost opportunities are expected to have the same load shape as that prevailing in the irrigation sector in general.

Some of the conservation measures identified as lost opportunities in this study are symbiotic with other measures in the sense that their energy savings are influenced by the installation of other measures, or their installation can influence the energy savings of other measures. Symbiotic relationships applying to the identified lost opportunities are:

- Proper pump selection is symbiotic with irrigation scheduling because flow rate is important in determining the proper length of irrigation sets; if a pump is replaced with one that has a significantly different flow rate, a farmer may need to modify his scheduling practices. 
- Proper pump selection is symbiotic with low-pressure irrigation because the required pressure of an irrigation system is an important determinant of the amount of operating head that a pump should produce.

Based on the results of this study, it is recommended that any further consideration of existing lost opportunities in the irrigation sector be concentrated on the measures of proper pump selection and high-efficiency motors. These two measures appear to represent the most significant lost opportunities that currently exist because they apply to existing, as well as new, irrigated acres. 
CONTENTS

SUMMARY . . . . . . . . . . . . . . . . . . . .

1.0 INTRODUCTION . . . . . . . . . . . . . . . . . . 1.1

2.0 IDENTIFICATION OF POTENTIAL LOST OPPORTUNITIES . . . . . . 2.1

2.1 POTENTIAL LOST OPPORTUNITIES ON EXISTING IRRIGATED ACRES $\quad 2.2$

2.2 POTENTIAL LOST OPPORTUNITIES ON NEW ACRES . . . . . . . 2.3

3.0 SURVEY METHODOLOGY AND RESULTS . . . . . . . . . . . . . 3.1

3.1 SURVEY RESULTS PERTAINING TO LOST OPPORTUNITIES ON

EXISTING ACRES . . . . • . . . . . . . . . . 3.1

3.2 SURVEY RESULTS PERTAINING TO LOST OPPORTUNITIES ON

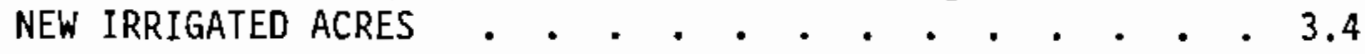

3.3 SUMMARY OF MAJOR SURVEY FINDINGS • • . . . . . . .

4.0 TECHNICAL AND ECONOMIC ANALYSIS OF SELECTED LOST OPPORTUNITIES. 4.1 REFERENCES. . . . . . . . . . . . . . . . . . . . R.1 Appendix A. . . . . . . . . . . . . . . . . . . A.1 


\section{TABLES}

3.1 Survey Participants. . . . . . . . . . . . . 3.2

4.1 Representative Costs For High-Efficiency Electric Motors . . . 4.3

4.2 Potential Energy Savings (Average Megawatts) In 5-Mill Cost Increments For Energy-Efficient Electric Motors On NewSprinkler Irrigated Acres in 2003 . . . . . . . . . . 4.4

4.3 Potential Energy Savings (Average Megawatts) In 5-Mill Cost Increments For Energy-Efficient Motors On Existing Sprinkler Irrigated Acres .............. 4.4 


\subsection{INTRODUCTION}

The purpose of this paper is to identify and analyze conservation measures in the irrigation sector of the Pacific Northwest that may potentially be regarded as "lost opportunities". The paper will descibe potential lost opportunities, determine the importance of these lost opportunities to regional power planning activities, and present the results of a technical and economic analysis of selected opportunities. So far as possible, the paper will attempt to be consistent with similar analyses developed for other conservation sectors (residential, commercial, industrial). However, a number of factors, including the potential of a lost opportunity to facilitate fuel-switching to electricity and its peaking load shape impacts, are not relevant to irrigation sector conservation measures.

This study is being conducted in association with an overall research and planning effort being conducted by Bonneville to deal with issues related to lost opportunities for conservation. Currently, the Pacific Northwest regional power system is in a surplus situation and the impetus for obtaining energy savings through conservation has been reduced. However, there may be certain conservation measures that are currently cost-effective for which savings may be prohibitively expensive or technically infeasible to obtain in the future. Bonneville requested that these lost opportunities be initially identified and characterized so that more detailed cost and poljcy evaluations could be undertaken in the future.

The paper is divided into three chapters. The first chapter describes the procedures used in identifying potential lost opportunities for more detailed characterization. The second chapter presents the procedures and results of a survey used to gather more detailed information on potential lost opportunities. The final chapter of the paper presents the results of a technical and economic analysis of two identified lost opportunities in the irrigation sector - low-pressure irrigation on new handmove/sideroll systems and high-efficiency electric motors. 


\subsection{IDENTIFICATION OF POTENTIAL LOST OPPORTUNITIES}

A "lost opportunity" is defined as a conservation measure that may be prohibitively expensive or substantially less effective in saving energy if its implementation is delayed until such time as the energy savings from the measure are needed on the regional power system. An example of a lost opportunity in the residential sector would be energy-saving window orientation and design on a new home that would not be cost-effective to retrofit after the home is constructed.

Initially, Bonneville's general criteria for determining a lost opportunity is that there be no opportunity to implement the measure within 10 years of its current installation, that implementing the measure in the future would cost at least 50 percent more, or that savings will decrease by 30 percent if the measure is implemented at a later date. In addition, measures to be considered as potential lost opportunities are to be limited to those currently included in BPA's conservation resource portfolio. These criteria were developed as an initial starting point for identifying and characterizing lost opportunities with the expectation that they may be modified at a later date. The final limitation listed above is not followed in this paper so that additional conservation measures that may represent possible lost opportunities may be identified for consideration.

The process of identifying potential lost opportunities in the irrigation sector was as follows:

- A preliminary issue paper that attempted to define potential lost opportunities was developed by Pacific Northwest Laboratory (PNL) for Bonneville review.

- Discussions were held between PNL and Bonneville personnel familiar with the irrigation sector concerning the definition of potential lost opportunities in the sector.

- A final issue paper was developed and submitted to Bonneville to guide further investigative activities pertaining to lost opportunities in the irrigation sector.

The results of this identification process are described below. 


\subsection{POTENTIAL LOST OPPORTUNITIES ON EXISIING IRRIGATED ACRES}

Conservation measures currently included in BPA's resource portfolio for existing irrigated acres include low-pressure on center pivot, low-pressure on handmove/sideroll, fittings design improvements, mainline enlargement, and irrigation scheduling. It would appear that none of these measures on existing irrigated acres represent lost opportunities. Existing irrigated acres change very little over time and irrigation systems generally have expected lifetimes exceeding 20 years. It appears that the costs of implementing the measures on existing systems 10 years from now would not be significantly different from the costs of implementing the measures today. In addition, the energy savings of the measures should not be impacted by a delay in implementation.

The only potential "lost opportunity" on existing irrigated acres that is identified for consideration may be improved pumping plant efficiency. Irrigation pumps and motors are generally replaced more often than the irrigation systems that they supply with water. Because of pump pulling costs and technical barriers, it would likely be significantly more effective to ensure that the pumps and motors used in replacement are energy efficient at the time of replacement rather than attempting to improve their efficiency at a later date. Proper matching of pump and motor characteristics with irrigation system requirements is a key element in determining the operating efficiency of a pumping plant. Thus, foregoing the use of energy-efficient pumps and motors at the time of pumping plant replacement may potentialiy represent a lost opportunity.

Except for the cost of purchasing a high-efficiency motor, the difference in cost between an efficient pump and an inefficient pump at the time of installation would likely not be significant. In some cases, a more energy-efficient pump that was more accurately matched to system pumping requirements would actually cost less, because it would be smaller than a less energy-efficient pump. Thus, the main issue concerning the potential lost opportunity of proper pump selection would appear to be having the knowledge and information base necessary to select the correct pump for system requirements. High-efficiency motors do have higher initial capital costs than standard efficiency motors and thus, may be considered a potential lost 
opportunity that may require economic incentives to facilitate widespread adoption.

Based on the findings presented above, it was decided that further analyses of lost opportunities on existing acres be concentrated on three issues:

1) the timing of pump repair and/or replacement in irrigation systems,

2) the methods used in selecting a pump to replace an existing pump, including pump sizing criteria and importance of energy efficiency,

3) the incremental costs of energy-efficient motor purchase.

The timing of pump repair and/or replacement is identified as an issue relevant to identification of lost opportunities because of the criteria for a lost opportunity that there be no opportunity to implement a conservation measure within 10 years of its current installation. If irrigation pumps receive major overhauls or are replaced more frequently than every 10 years, then they would not be classified as lost opportunities under this criteria.

Pump selection methods are identified as a relevant issue in terms of confirming or refuting the hypothesis that the primary barrier to the installation of energy efficient pumps is knowledge and information. The final issue of the incremental costs of high-efficiency motors was analyzed in a recent study performed by PNL for Bonneville (Harrer and Wilfert 1987). The results of this analysis are summarized here so that the potential for high-efficiency motors as a lost opportunity can be explicitiy defined.

\subsection{POTENTIAL LOST OPPORTUNITIES ON NEW ACRES}

Conservation measures currentiy incorporated in BPA's resource portfolio for new irrigated acres also include low-pressure on center-pivot, low-pressure on handmove/sideroll, fittings design improvements, mainline enlargements, and improved irrigation scheduling. Except for improved irrigation scheduling, which is paid for on an annual rather than a first-cost basis, all of these measures can potentially be considered lost opportunities on new acres.

Low-pressure on center-pivot is obviously more cost-effective to implement on new acres at the time they are initially developed compared to later 
implementation. However, previous analyses (Lezberg and Harrer 1984) have found that the costs of low-pressure on new center-pivot acres are not significantly different from the costs of alternative high-pressure systems. In addition, it is not clear whether any center-pivot manufacturers are still selling high-pressure center-pivot systems, except in rare cases where such systems are required because of severe soil erosion problems. Thus, although low-pressure on center-pivot may conceptually represent a lost opportunity, in practice it may be of little importance to conservation resource planning. This issue will be investigated simply by asking irrigation equipment dealers questions about the incremental costs and usage of low-pressure center pivots.

Installing efficiently designed fittings and iarger mainlines at the time of the development of new irrigated acres is more cost-effective than delaying installation. In general, the difference in costs should be equal to the difference between the costs of installing these measures on new acres and the costs of installing them on existing acres. These cost differences may well be large enough to consider the installation of these measures on new acres to be lost opportunities.

However, the conservation measure of efficiently designed fittings was found in a previous analysis (Lezberg and Harrer 1984) to be too undefined to be subjected to detailed cost analysis and thus, is not the subject of such analysis in this study. In addition, the total energy savings from efficiently designed fittings on new sprinkler acres are estimated in Bonneville's current irrigation sector resource portfolio to be only about 2.5 average MW. Thus, the omission of this measure from detailed consideration as a lost opportunity will likely have little impact on the estimated irrigation sector conservation resource potential.

The installation of larger mainlines on new irrigated acres is analyzed in this study as a potential lost opportunity. This analysis is focused on whether the costs of waiting to install a larger mainline exceed the costs of installing the mainline at the time of new acreage development by more than 50 percent.

The installation of low-pressure on handmove/sideroll systems may potentially be considered a lost opportunity. Previous studies have found that irrigators with hand move/sideroll systems are more likely to adopt 
low-pressure on these systems if the spacing between their sprinkler risers is originally designed to be 50 feet or less. This causes the use of off-setting to be unnecessary. However, some additional costs would likely be associated with installing the additional equipment necessary to obtain 50-feet or less spacing between risers.

Conservation measures that are currently not included in BPA's resource portfolio, but may be considered lost opportunities, include energy-efficient pumps and motors and efficient piping design. Similar to the arguments presented for existing acres, it would appear to be much more cost-effective to install energy-efficient pumps and motors at the time of the initial development of new acres than it would be to retrofit these measures at a later date. In addition, the proper sizing of pipes throughout the irrigation system may produce energy savings that would not be cost-effective to obtain at a later date.

Analysis related to lost opportunities on new irrigated acres is focused on the following issues:

1) identifying the characteristics of any new irrigated acres that may have been installed during the last three years, including the energy use characteristics of these acres;

2) examining the methods used in designing an irrigation system for use on new irrigated acres;

3) estimating the incremental costs and measure lives of installing larger mainlines and handmove/sideroll systems with narrower riser spacing on new acres.

The analysis of the characteristics of new irrigated acres will determine what types of new irrigated acres are currently coming on-line so that the magnitude of potential lost opportunities can be gauged. Because of the poor economic state of irrigated agriculture, it is possible that the issue of lost conservation opportunities on new irrigated acres may currently be of little importance because so few new irrigated acres are currently being developed.

Examination of the design methods used for these irrigated acres will indicate the levels of awareness concerning the energy consumption features 
of new irrigated acres. The final element of the analysis will determine the incremental costs of those conservation measures that are believed to be among he most important potential lost opportunities in the irrigation sector low-pressure irrigation on handmove/sideroll systems and larger mainline installation.

The first part of the analysis of identified potential lost opportunities in the irrigation sector was conducted by surveying irrigation equipment dealers, pump repairers and county extension agents concerning various issues related to these opportunities. The results of this survey are reported in the next section of this report. 


\subsection{SURVEY METHODOLOGY AND RESULTS}

A number of irrigation equipment dealers, repairers and county extension agents around the Pacific Northwest were contacted by phone to discuss energy efficiency awareness and its application to new and existing sprinkler irrigation systems. The extent to which irrigators are concerned about the energy efficiency of the equipment they purchase was addressed. Types of sprinkler systems sold for use on new acreage in the last five years, including conversions to new systems, were evaluated. The extent of low-pressure utilization on handmove and sideroll systems was emphasized in the survey in hopes of understanding its seemingly low usage.

Information concerning the efficiency of pumps, their expected lifespans and their maintenance requirements were examined. Additionally, recommendations regarding a program to facilitate energy efficiency on new irrigated acres were sought, including information about who would be involved in the program and the goals of such programs. The questionnaire used in the survey is presented in Appendix A.

The individuals surveyed in the study included 10 irrigation equipment dealers, 6 pump repairers and 3 county extension agents. These individuals represented a broad cross-section of geographic areas in the Pacific Northwest. A listing of the survey participants is provided in Table 3.1.

\subsection{SURVEY RESULTS PERTAINING TO LOST OPPORTUNITIES ON EXISTING ACRES}

Because pumping plant efficiency improvements were identified as the only potential lost opportunity on existing irrigated acres, survey questions and analyses were concentrated in this area. Issues addressed included frequency of pump maintenance and repair, expected lifetimes of pumps, and the incremental costs of high-efficiency electric motors.

Most pump repairers in the survey see a tendency among irrigators to undertake a major overhaul of a used pump before replacing it. This was attributed to the high cost involved with replacement versus repair in a time of poor economic conditions in the agricultural sector. 


\section{TABLE 3.1. SURVEY PARTICIPANTS}

\section{Irrigation Equipment Dealers}

- Burt Hansen, Jr., Hansen Irrigation, Idaho Falls, Idaho

- Don Mulkey, Stadeler Pump, Mt. Anger, Oregon

- Kent Kidd, Silver Creek Irrigation Co, Jerome, Idaho

- Alan Blize, Ag-Sales Co., Missoula, Montana

- Bruce Hurtado, Lad Irrigation, Moses Lake, Washington

- Dale Petty, Irrigation Sales Inc., Toppenish, Washington

- Leon Mecham, Golden West Irrigation, Idaho Falls, Idaho

- Merv, Yakima Implement and Irrigation, Yakima, Washington

- Dan Nygren, Kerns J.W. Irrigation Co., Klamath Falls, Oregon

- Becky Davis, Wolfjohn \& Associates, Pasco, Washington

\section{Pump Repairers}

- Ted Hilton, Irrigation Specialists Pasco, Washington

- Dan Holton, BZH Precision Machines, Pasco, Washington

- Keith Newton, Newton Pump, Inc., Redmond, Oregon

- Helen Campbe1l, Interstate Pump, Inc., Klamath Falls, Oregon

- Ed Walker, Walker Pump, Inc., Idaho Falls, Idaho

- Mr. and Mrs. Farr, Valley Pump and Equipment Co., Klamath Falls, Oregon

\section{County Extension Agents}

- Dennis Kincaid, Snake River Conservation Research Center, Kimberly, Idaho

- Dorrell Larsen, University of Idaho, Parma, Idaho

- Marvin Young, Oregon State University, Dechutes County, Oregon 
With respect to pump maintenance schedules most repairers agreed that routine upkeep must be done on a yearly basis to insure an efficient pump. Upkeep was seen as being the responsibility of the irrigator himself. A major pump overhaul, on the other hand, is normally done by a qualified pump repairer, unless an irrigator is extremely sophisticated in this area. Three to five years was the expected timing of a pump overhaul. Timing of pump maintenance and repair was determined by many factors. The amount of sand in the water, annual usage, and the age of the pump were listed as major determinants.

There is some disagreement among repairers concerning the efficiency of pumps today as compared to those installed 5-10 years ago. Approximately half of the repairers feel that pumps have changed very little over the last 10-20 years and that a pump today is not significantly more efficient than those installed 5-10 years ago. The remaining $50 \%$ of the repairers fee 1 differently. They believe that a pump sold today is more energy efficient than one sold 5-10 years ago due to recent updated designs and increased testing before selling to the public.

Though these views are conflicting, all repairers agree that energy efficiency has become a greater concern among irrigators, and that they are becoming more conscientious regarding pump maintenance practices in hopes of reducing their energy use. Energy efficiency is seen as being dependent on the pump purchased, as well as proper mainline sizing, correct installation, and maintenance schedules.

The process of selecting a pump for use in an irrigation system was found to be non-standarized, with about half of the irrigation dealers indicating that they actively work with irrigators in selecting a pump and the other half indicating that irrigators basically purchased pumps "off-the-shelf" with little design consultation. The sophistication of equipment dealers regarding issues related to pump selection was found to vary widely, and improperly selected pumps are likely to be relatively prevalent.

When it came to the expected life of a pump, most repairers questioned felt that pumps sold today had a similar life span to those sold 10 years ago. The average life expectancy of a irrigation pump depending on the type 
of pump, annual usage, maintenance practices, and environmental conditions (i.e., freezing, sand in water) was estimated by pump repairers and dealers as being 10-15, years which is similar to a pump installed 10 years ago.

Most equipment dealers and pump repairers questioned felt that an irrigation system motor would last at least as long or longer than an irrigation pump. These responses provided a basis for an assumption that the expected measure life for an electric motor used in an irrigation pumping plant should be 15 years. When asked about the cost differential between varying levels of efficiency in pumps, less efficient pumps were seen as costing approximately the same as more efficient ones. However, most dealers indicated that higher costs would be associated with high-efficiency electric motors compared to standard-efficiency motors. One dealer placed the cost difference at approximately 20 percent.

\subsection{SURVEY RESULTS PERTAINING TO LOST OPPORTUNITIES ON NEW IRRIGATED ACRES}

There is a general consensus among deaiers, repairers, and county extension agents that the total number of sprinkler irrigated acres will remain the same or decrease over the next five years. Low crop prices, depreciating land values, and irrigators going out of business will all contribute to this stagnation of growth. Basically, any new sprinkler acres will be offset by acres withdrawn from irrigation.

of the sprinkler irrigation systems sold by Pacific Northwest dealers over the last five years, only 10-20\% were reported as representing the development of new irrigated land. The remainder were conversions from flood or drip to sprinkler and the replacement of existing systems.

According to all of the dealers contacted, very few sideroll and handmove systems sold in the last five years utilized low-pressure sprinklers. The lack of low-pressure usage was attributed to the following:

1. Use of $40^{\prime} \times 60^{\prime}$ spacing versus $40^{\circ} \times 50^{\prime}$ spacing, due to the use of $6^{\prime}$ wheels.

2. The belief that $40^{\prime} \times 60^{\prime}$ spacing leaves "dry spots" with low-pressure utilization.

Forty by $60 \mathrm{ft}$ spacing is preferred over $40 \times 50 \mathrm{ft}$ spacing because of 
the common use of $6^{\prime}$ wheels. With $6^{\prime}$ wheels, sideroll systems won't roll $50^{\prime}$ in even increments. Rolling 60', however, with a $6^{\prime}$ wheel produces even increments. A $5^{\prime}$ wheel would roll $50^{\prime}$ in even increments, but irrigators are apprehensive about the use of smaller wheels due to the fear of crushing high-standing crops like grains. Therefore, since $6^{\prime}$ wheels are most common, $40^{\prime} \times 60^{\prime}$ spacing is preferred.

Unfortunately, dry spots are associated with $40^{\prime} \times 60^{\prime}$ spacing utilizing low pressure. Irrigators feel that this combination (low pressure and $40^{\prime} x$ $60^{\prime}$ spacing) leads to uneven sprinkling and saturation. The net effect is undesirable, so very few low-pressure systems are being installed on $40^{\prime} x$ $60^{\prime}$ spacings. For even saturation, most irrigators believe that at least $40^{\prime}$ $\times 50^{\prime}$ spacing (if not $40^{\prime} \times 40^{\prime}$ spacing) must be used, but the traditional $6^{\prime}$ sizing of wheels inhibits such spacing. In addition, familiarity with the technique of "offsetting" sprinkler sets on $40^{\prime} \times 60^{\prime}$ spacing appears to be relatively low.

In the Idaho Falls area where $70 \%$ of the handmove/sideroll systems installed by Burt Hansen, Jr., of Hansen Irrigation utilize $40^{\prime} \times 50^{\prime}$ spacing, it was interesting to note that only an estimated $10 \%$ have low-pressure sprinklers. Burt Hansen, Jr., attributed this low usage to the following:

1. Most systems were installed before low-pressure existed.

2. Those wishing to convert to low-pressure usually would make a major change to center pivot (with low-pressure).

3. Where center pivot systems were inappropriate, most felt that the energy cost savings associated with converting a handmove/sideroll system to low-pressure were not enough to offset the cost of conversion.

The cost of converting $40^{\prime} \times 60^{\prime}$ spacing to either $40^{\prime} \times 50^{\prime}$ or $40^{\prime} \times$ $40^{\prime}$ spacing after initial system installation to take advantage of low-pressure energy reductions is expensive and impractical. However, when a new system is installed, the cost difference, as calculated by a few dealers, of $40^{\prime} x$ $60^{\prime}$ spacing compared to $40^{\prime} \times 50^{\prime}$ is negligible. Spacing of $40^{\prime} \times 50^{\prime}$ necessitates the use of an additional 3-4 risers which amounts to approximately a $\$ 200$ increase over $40^{\prime} \times 60^{\prime}$ spacing. 
No cost increase appears to be associated with low pressure on new center pivots. Survey participants estimated that roughly $90-95 \%$ of the center pivot systems they had sold and installed in the last five years were low-pressure spray or impact systems. Industry beliefs concerning possible energy savings with low-pressure on center pivots are favorable, as evidenced by its high usage rate. High-pressure sprinklers have become an obsolete technology on new center pivots, reserved for use on only a small number of irrigated acres where runoff problems prevent the use of high-pressure systems.

The potential for mainline modification to represent a lost opportunity was examined by obtaining estimates of the relative costs of materials purchase versus installation costs for 900' of 6-inch and 12-inch PVC pipe. The assumption is that only additional installation costs would be associated with increasing mainline size after the mainline was originally installed. Materials purchase costs associated with a larger mainline would be equal at the time of original installation to those that would be incurred at a later date. Thus, if total mainline purchase and installation costs are not $50 \%$ higher than mainline purchase costs alone, then mainline modification on new acres would not represent a lost opportunity.

Data obtained from irrigation equipment dealers revealed that total purchase and installation costs for 900' of 6-inch PVC pipe cost an average of approximately 55 percent more than the purchase costs for the pipe. Total purchase and installation costs for $900^{\prime}$ of 12-inch PVC pipe cost an average of approximately 20 percent more than the purchase costs for the pipe. Thus, under the 50 percent cost increase criteria, 6-inch mainline pipe could marginally be considered a lost opportunity, while 12-inch mainline pipe could not.

The educational process of teaching irrigators about the long-run savings associated with the implementation of low-pressure systems, larger mainlines and high-efficiency motors, which can be more expensive in the short-run to install, is not universal among dealers, as yet. Some dealers use computer simulations to convey expected savings over time to irrigators taking soil conditions, wind, and topography into account, while others lacking in their degree of education concerning energy conservation methods, offer little if any technical assistance to customers. 
Energy efficiency is a greater concern among irrigators purchasing a new irrigation system today than it was 10 years ago, according to irrigation equipment dealers. However, depending on the sophistication of the dealer and the agricultural region, the degree to which this concern is put into practice by actually purchasing an energy efficient system will vary. For example, in western Idaho, most irrigators have little faith in low-pressure systems believing they do not work, according to Kent Kidd of Silver Creek Irrigation Co.. Here, very few low pressure conversions and sales take place. In eastern Idaho, however, the majority of systems utilize low pressure. Mr. Kidd feels that this dramatic difference in opinion and usage is due to differences in the level of education by irrigators, and a lack of convincing data showing actual savings.

There is a general belief, however, among dealers questioned that when a new system is being purchased, most irrigators will inquire about and purchase an energy-efficient system. The general consensus is that more education of both dealers and irrigators is necessary to facilitate the application of energy-efficient features within irrigation systems.

Many recommendations were made by survey respondents to overcome this educational deficiency. Both end users (irrigators) and equipment suppliers (dealers) were seen as needing more information regarding energy efficient practices. Possible educational sources included:

- universities

- extension services

- power/utility companies

- trade programs

- news/media

- soil conservation agents

- system designers

- manufacturers

- BPA 
- irrigation equipment suppliers

- consultants

Though the groups listed above may already have available information on irrigation system energy-efficiency, the problem lies in actually distributing it to end-users in an appropriate fashion, according to survey respondents. Assuming that irrigators are interested in cost savings, programs offered to assist in the adoption of new energy-efficient systems would be viewed favorably.

Recommended programs to disperse educational information included; maintenance schools, local and regional trade shows, utility informational brochures, university sponsored seminars, and local farming news letters. Though many of these programs are already in existence, there is a general feeling that awareness about them is low. It was generally felt that both dealers and irrigators would benefit from participation in these programs. However, initial awareness about the programs being offered needs to be increased before any increase in participation is expected.

\subsection{SUMMARY OF MAJOR SURVEY FINDINGS}

The major results derived from the survey of irrigation pump repairers, equipment dealers and county extension agents with reference to lost opportunities can be summarized as follows:

- Pump efficiency improvements through improved maintenance do not represent a lost opportunity because their measure life will normally be 5 years or less.

- No major hardware design changes to improve the efficiency of irrigation pumps represent lost opportunities because such hardware changes are either unavailable or their incremental costs are negligible.

- Proper pump selection does represent a lost opportunity because it is a major influence on pumping plant energy efficiency, it is difficult or impossible to modify an improperly selected pump once it is installed, and it has a measure life exceeding 10 
years.

- High-efficiency electric motors represent a lost opportunity on both existing and new acres because they have a measure life that should normally exceed 10 years, there is no way to practically improve motor efficiency after a motor has been installed and some incremental costs are associated with the initial purchase of high-efficiency motors.

- Low-pressure on handmove/sideroli systems on new acres represent a lost opportunity because low-pressure adoption is unlikely unless 40 $x$ 50' spacing is utilized on such systems and redefining the spacing of handmove/sideroll systems after initial system installation is impractical.

- Mainline modification on new acres generally does not represent a lost opportunity because the incremental costs associated with installing a paralell mainline at a later date will generally be less than 50 percent higher than installing a larger mainline at the time of new system installation.

- Lost opportunities on new irrigated acres do not currently appear to be an issue of much importance because so few new irrigation systems are currently being installed and most dealers/extension agents expect this situation to continue for the next several years.

- Education continues to be a major barrier to irrigator adoption of energy conservation measures.

Based on this analysis, it appears that the only lost opportunities of major concern would appear to be proper pump selection methods, high-efficiency electric motors and low-pressure on new handmove/sideroll systems. other conservation measures in the irrigation sector either do not meet Bonneville's criteria for a lost opportunity or are of little significance in terms of their energy savings potential. This does not imply that research and education related to other measures should not be continued. It appears that a lack of information on conservation measures delivered to both equipment dealers and irrigators continues to represent a major impediment to the adoption of all types of these measures by irrigators. 
Informational barriers appear to be a particularly significant constraint on the identified lost opportunity of proper pump selection. Purchasing a pump that is properly matched to irrigation system requirements should normally not cost any more than purchasing an improperly matched pump, and may cost less because of the tendency of irrigators to buy a larger pump than is really needed. Thus, little or no acquisition costs would be associated with addressing this lost opportunity. Costs that would be incurred include those associated with the development of informational materials and a program to disseminate these materials to equipment dealers and irrigators. The energy savings from improving pump selection methods would likely fall in the range of 5 to 10 average $\mathrm{MW}$. 


\subsection{TECHNICAL AND ECONOMIC ANALYSIS OF SELECTED LOST OPPORTUNITIES}

The two conservation measures selected for technical and economic analyses are high-efficiency electric motors and low-pressure on handmove/sideroll systems. The results of these analyses for each of these measures are discussed in turn.

Although the conservation measure of low-pressure on new handmove/sideroll systems was selected for detailed analysis, it currently appears to be of little significance because so few new handmove/sideroll systems are currently being installed. However, it is believed that, in the absense of major changes in low-pressure technology, the continued use of $40^{\prime} \times 60^{\prime}$ spacing on handmove/sideroll systems will constitute a major barrier to the adoption of low-pressure irrigation.

Continued resistance to the use of low-pressure on handmove/sideroll systems could have a significant impact on the conservation resource potential in the irrigation sector. This measure is currently estimated to have the largest potential energy savings potential of any single conservation measure in the irrigation sector. The estimated savings potential for low pressure on handmove/sideroll systems of over 45 average MW, comprises over one-third of the total energy savings currently estimated to be available in the sector.

The average costs per $\mathrm{kWh}$ saved of low-pressure on handmove/sideroll systems on new acres were previously estimated to be 7.5 mills in Bonneville's conservation resource profile (Harrer, et. al., 1984). This estimate was based solely on an assumed increase in operating and maintenance costs associated with off-setting of $\$ 1$ per acre. It seems doubtful that the $\$ 200$ of additional capital costs associated with a few extra risers for $40^{\prime} \times 50^{\prime}$ spacing would impact significantly on the costs per kwh saved for low-pressure on handmove/sideroll. Thus, these costs were not reestimated in this study. It is believed to be extremely doubtful that these costs would exceed 10 mills per kWh saved.

It appears that the major impediment to the use of low-pressure on sideroll systems is more related to technical engineering design considerations rather than initial capital cost considerations. The prevalent use of $6^{\prime}$ wheels on sideroll systems practically requires $40^{\prime} \times 60^{\prime}$ spacing on sideroll 
systems.

The long-run cost savings associated with the use of low-pressure on handmove/sideroll systems do not appear to have been sufficiently demonstrated to irrigators. It appears that neither equipment designers nor irrigators have placed the same priority on reducing the energy use of handmove/sideroll systems as they have placed on center-pivot systems.

Based on previous conservation resource supply curve estimates, the energy savings potential associated with the lost opportunity of low-pressure on handmove/sideroll systems on new acres is approximately 7 average MW. In addition, capturing this lost opportunity could have a spinoff effect of facilitating the adoption of low pressure on existing handmove/sideroll acres. Continued research and demonstration related to this conservation measure is recommended if this potential is to be realized.

As described previously, the lost opportunity of high-efficiency electric motors applies to both existing and new acres. Replacing a standard electric motor with a high-efficiency motor is prohibitably expensive unless the standard electric motor requires replacement because it has worn out. At the time of motor replacement, the only costs associated with a high-efficiency motor are the incremental costs associated with purchasing a high-efficiency motor rather than a standard motor. Representative estimates of these incremental costs are provided in Table 4.1. Costs associated with replacing an operational standard electric motor after it has been installed would be significantly higher than the incremental costs shown in Table 4.1 and would exceed the 50 percent cost criteria currently used by Bonneville in defining "lost opportunities". 
TABLE 4.1. Representative Costs for High-Efficiency Electric Motors (a)

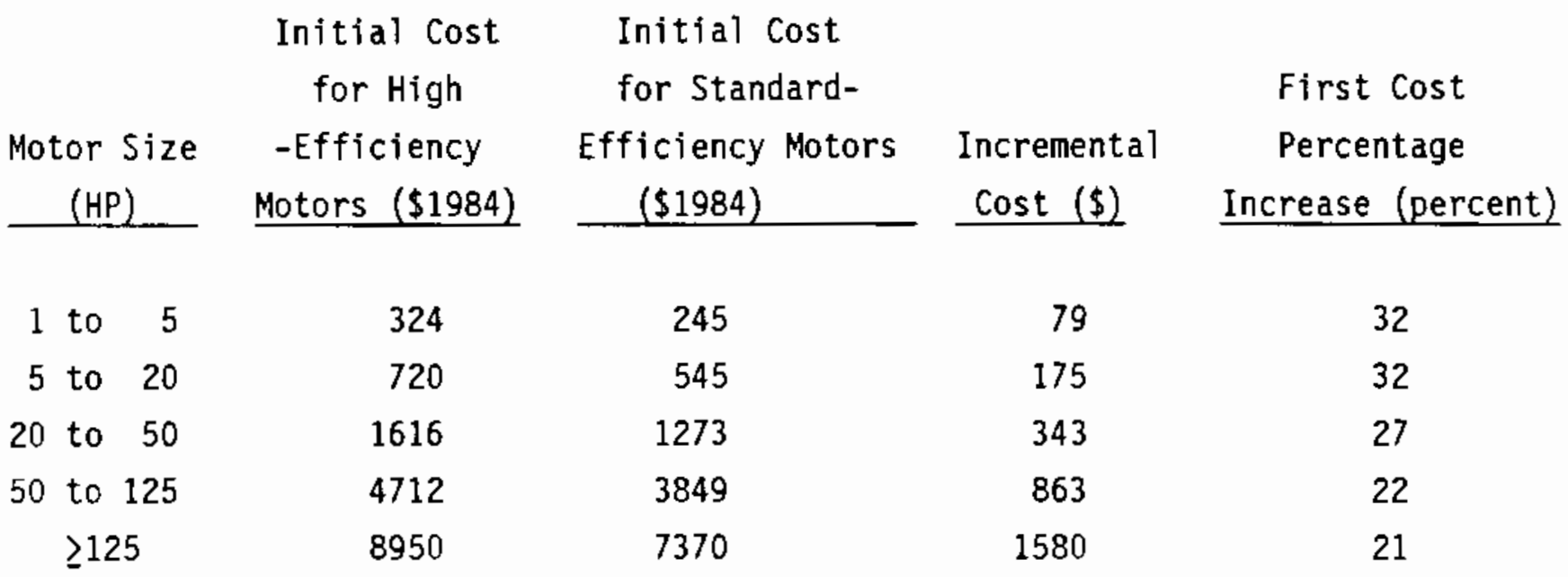

(a) Source: Calculated from data presented in Siemans-Allis Selection and Pricing Guide--Integral Horsepower AC Motors, 1984 and Century Electric Product Catalogue, 1984.

A representative incremental capital cost for high-efficiency motors of $\$ 865$ or $\$ 6.65$ per acre for a 130-acre field was chosen for use in estimation. An assumption that high-efficiency motors would improve irrigation pumping plant efficiencies by an average of three percentage points was also utjlized in the analysis.

The assumed levels of incremental costs and energy efficiency improvements available from high-efficiency motors were then input to the Irrigation Sector Energy Planning (ISEP) model used to develop Bonneville's conservation resource supply curves. The results of this process are shown in Tables 4.2 and 4.3. Note from Tables 4.2 and 4.3 that the lost opportunity of high-efficiency motors is estimated to involve over 5 average MW of savings on new sprinkler irrigated acres and almost 11 average MW on existing acres. Most of these savings could be obtained for 25 mills per kth saved or less. 
TABLE 4.2 Potential Energy Savings (Average Megawatts) in 5-Mill Cost Increments for Energy-Efficient Electric Motors(a) on NewSprinkler Irrigated Acres in 2003

Irrigation System/ Acreage Type

Center-Pivot Using Surface Water

Center-Pivot Using Ground Water

Handmove/Sideroll Using Surface Water handmove/Sideroll Using Groundwater Al 1 New-Sprinkier Acres

\section{Cost-Increment}

$\begin{array}{cccccccccc}\frac{5}{0} & \frac{10}{.02} & \frac{15}{.03} & \frac{20}{.12} & \frac{25}{.27} & \frac{30}{.40} & \frac{35}{.52} & \frac{40}{.52} & \frac{45}{.52} & \frac{50}{.52} \\ 0 & .16 & .53 & .55 & .59 & .59 & .59 & .59 & .59 & .59\end{array}$

$\begin{array}{llllllllll}0 & .05 & .11 & .41 & .92 & 1.26 & 1.26 & 1.26 & 1.26 & 1.26\end{array}$

$\begin{array}{llllllllll}.44 & 1.28 & 2.74 & 2.78 & 2.80 & 2.87 & 2.94 & 2.97 & 2.97 & 2.97\end{array}$

$\begin{array}{llllllllll}.44 & 1.51 & 3.41 & 3.86 & 4.58 & 5.12 & 5.31 & 5.34 & 5.34 & 5.34\end{array}$

TABLE 4.3 Potential Energy Savings (Average Megawatts) in 5-Mill Cost Increments for Energy-Efficient Motors (a) on Existing Sprinkler Irrigated Acres

Irrigation System/ Acreage Type

Center-PIvot Using Surface Mater

Center-PIvot Using Groundwater

Hendrove/sIderoll Using Surface Water

Handmove/siderol I UsIng Groundwater

All ExIsting SprInkler Acres

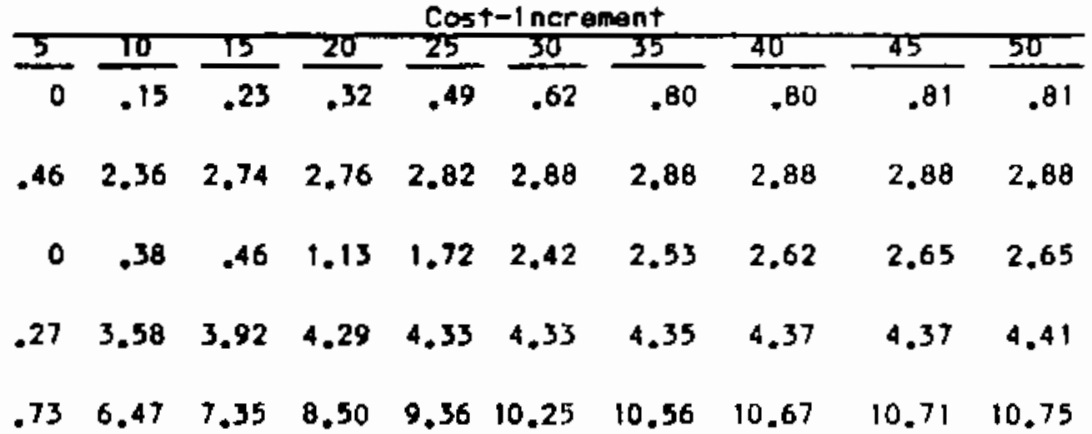
(a) All costs and onergy savings represent incremental costs and energy savings
compared to standard efficlency lectric notor. 


\section{REFERENCES}

Harrer, B.J. and A.J. Lezberg. 1984. Potential Conservation Opportunities from the Use of Low-Pressure Irrigation in the Pacific Northwest Region. PNL-5314. Pacific Northwest Laboratory, Richland, Washington.

Harrer, B.J., A.J. Lezbert, and G.L. Wilfert. 1985. An Integrated Assessment of Conservation Opportunities in the Irrigated Agriculture Sector of the Pacific Northwest Region. PNL-5406. Pacific Northwest Laboratory, Richland, Washington.

Harrer, B.J. and G.L. Wi]fert. 1987. Energy Efficiency of Pacific Northwest Agriculture Irrigation Pumping Systems. PNL-6194. Pacific Northwest Laboratory, Richland, washington. 


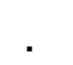

. 
APPENDIX A

QUESTIONNAIRES USED IN LOST OPPORTUNITIES SURVEY 


\section{QUESTIONS FOR IRRIGATION EQUIPMENT DEALERS}

(Note: Throughout survey, if respondent won't estimate percentages, ask for relative rankings or qualitative estimates)

1. What kinds of sprinkler irrigation systems have comprised your largest amount of sales over the last five years?

2. Please rank the following systems, in terms of the percent of total irrigation system sales they have comprised over the last five years:

- center-pivots, rank =

- sideroll systems, rank =

- handmove systems, rank =

- big-gun or solid-set systems, rank =

3. About what percent of the total center-pivot systems you have sold over the last five years were the following:

- low-pressure spray systems

- low-pressure impact systems

- high-pressure impact systems

4. About what percent of the sideroll systems you have sold in the last five years utilized low-pressure sprinklers?

5. About what percent of the handmove systems you have sold in the last five years utilized low-pressure sprinklers?

6. a) About what percent of the sprinkler irrigation systems that you have sold over the last five years would you say represented the development of new irrigated land?

b) About what percent of the sprinkler irrigation systems that you have sold over the last five years represented the conversion of flood or drip irrigated land to sprinkler irrigation?

c) About what percent represented replacement of existing irrigation systems? 
7. Please describe the process by which an irrigator and yourselves go about designing a new irrigation system for use on a specific field: (i.e. does the irrigator purchase the system right off the shelf, does the dealer analyze the irrigators' needs and provide recommendations, what kinds of design analyses to select systems, size pumps, and design pipe networks are typically performed?)

8. Is energy-efficiency a greater concern among irrigators purchasing a new irrigation system today than it was 10 years ago? What steps do you and your buyers take to insure that the new irrigation systems you install are as energy-efficient as possibie?

9. What are the installed costs of 900 feet of 6" PVC pipe? What is the breakdown between materials and installation costs for this pipe?

10. What are the installed costs of 900 feet of 12" PVC pipe? What is the the breakdown between materials and installation costs for this pipe? 
11. What percent of the new handmove/sideroll systems that you install have $40^{\prime} \times 50^{\prime}$ spacing? $40^{\prime} \times 60^{\prime}$ spacing?

12. Please estimate the costs of: 1) purchasing and installing a $40 \times 50^{\prime}$ sideroll system to irrigate a 20-acre field and 2) purchasing and installing a $40 \times 60^{\prime}$ sideroll system to irrigate a 20 -acre field:

13. If a program were made available to encourage the energy-efficient design of new irrigated acres, how would you suggest the program be organized? (i.e. who would be involved (dealers, utilities, SCS) and what should the program do?) 
14. Do you expect that the future rate of increase in sprinkler irrigated acres will increase, decrease, or remain about the same relative to the last five years? increase decrease about the same 


\section{QUESTIONS FOR IRRIGATION PUMP INSTALLATION/REPAIR PERSONNEL}

1. What comprises the majority of your work, new pump installation or repair of used pumps? (break out as $\%$ of total time)

\% new pump installation $\%$ used pump repair

2. Have you noticed a trend to repair rather than replace used pumps in the last 5-10 years? (yes or no) If yes, what do you feel might be the cause of this trend?

3. Do you feel that irrigation pumps today are more energy efficient than 5-10 years ago or have pump designs remained relatively unchanged?

4. What is the normal operating life of a pump installed 5 years ago? years What is the expected operation life of newer pumps? years Would you normally expect a pump installed today to last 10 years?

5. About how often would you say the following activities are performed?

1) routine pump maintenance = every years

2) major pump overhaul = every years

3) total pump replacement = every years 
6. What are common factors determining the timing of these activities?

7. On average how often does a pump require a repair which necessitates an actual trip to the shop? (i.e. remove pump from pump-pad) Do these repairs tend to be much more expensive than those which can be effected in the field? [try to get a cost range]

8. Are irrigators more aware of the efficiency of a pump than they were 10 years ago? (i.e. Do farmers inquire about energy consumption figures when gathering information for a purchase decision)

9. Please describe the process that you and a farmer go through in designing and selecting a pump for use on an irrigation system: (i.e. how is pump sized to match system requirements and how are energy efficiency concerns incorporated in the selection process)

10. Please rank from 1 to 5 the following factors in terms of their importance in reducing the energy efficiency of irrigation pumping plants:

- improper matching of pump to system needs (i.e. pump oversized) Rank =

- poor maintenance, Rank =

- $\quad$ pump manufacturers design not energy efficient, Rank =

- $\quad$ pump improperly installed, Rank = 
11. Do more energy efficient pumps tend to cost more or less than less efficient pumps? Explain:

12. What would you recommend in a program to encourage energy efficiency on new acres? 


\section{QUESTIONS FOR COUNTY EXTENSION AGENTS}

1. Do you have available any quantitative data regarding numbers of sprinkler irrigated acres?

$$
\text { yes } \quad \text { no }
$$

2. For what geographic area is this data defined?

3. What would you estimate has been the average number of additional sprinkler irrigated acres per year over the last 5 years? (include acres coverted from other systems)

(Average acres per year)

(Geographic area)

4. What does this increase represent as a percent of total sprinkler irrigated acres in your area?

5. Of the acreage figure given in Question 2 about what percentage is newly developed land from flood or drip \% and what percent is system conversion

5. What is the breakdown of these new sprinkler irrigated acres by type of system? (ask ejther on a number of acres or on a percentage basis)

$$
\text { Number of Acres or } \% \text { of Total new sprinkler acres }
$$

Center-pivot

Handmove

Sideroll

other (solid-set, big gun) 
7. About what percent of the center-pivot systems installed over the last three years were the following:

- low-pressure spray systems

- low-pressure impact systems

- high-pressure impact systems

8. About what percent of the sideroll systems that have been installed in the last three years utilized low-pressure sprinklers?

9. About what percent of the handmove systems that have been installed in the last three years utilized low-pressure sprinklers?

10. Do you feel that the future rate of sprinkler system installation will increase or decrease from what it has been in the last 5 years?

increase decrease stay the same

11. Is the energy efficiency of an irrigation system a greater concern today than it was 10 years ago?

12. Do you feel that the sprinkler systems that have been installed recently are as energy efficient as possible?

13. What would you recommend in a program to encourage energy efficiency on new acres?

14. If they have actual data on sprinkler irrigated acres ask them to send the data and provide an address: 


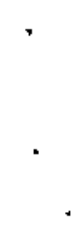




\section{DISTRIBUTION}

No. of

Copies

OFFSITE

2 Curt Hickman

Bonneville Power Administration

P. 0. Box 3621

Portland, Oregon 97208

Fred Gordon

Bonneville Power Administration

P. 0. Box 3621

Portland, Oregon 97208

Steve Levy

Bonneville Power Administration

P. 0. Box 3621

Portland, Oregon 97208

John Wilkens

Bonneville Power Administration

P. 0. Box 3621

Portland, Oregon 97208

30 DOE Technical Information Center

Mary Corrigan Department of Energy

Forrestal Building

1000 Independence Ave., S.W.

Washington, DC 20585
No. of

Copies

ONSITE

OOE Richland Operations Office

J. J. Sutey

9 Pacific Northwest Laboratory

B. L. Mohler

B. J. Harrer

Publishing Coordination

MH (2)

Technical Report Files (5) 
